\title{
Verification of soil moisture simulating accuracy on dry-land winter wheat and spring maize field by EPIC model on the loess plateau of china
}

\begin{abstract}
EPIC model is an effective tool to simulate soil water which is the key factor to influence the crop production on the Loess Plateau of China. So there is a practical meaning to evaluate the simulation results of soil water. In Loess Plateau amount of rainfall varies greatly throughout the year. So it's annually and monthly distribution has a great significance for the development of crop production and recovery of soil moisture in different layers. In this study, the accuracy of simulated monthly soil moisture was assessed, based on measured monthly soil moisture ( $0-2 \mathrm{~m}$ soil layer) data from 1987 to 1996 at Changwu Agricultural Station. Results showed that RRMSE (Relative Root Mean Square Error) between simulated and measured soil moisture $(0-2 \mathrm{~m}$ soil layer) in winter wheat field and spring maize field was $2.8 \%$ and $-0.2 \%$ respectively, the value for RMSE (Root Mean Square Error) was $0.023 \mathrm{~m} / \mathrm{m}$ and $0.015 \mathrm{~m} / \mathrm{m}$ respectively. The accuracy of simulated soil moisture influenced by the precipitation amount of simulated years were lower in extreme rainfall years (extreme rainy years and extreme drought years) than in other rainfall years. Therefore, the modified EPIC model predicted well soil water in different soil layers and provided basis for the EPIC users to research the law of soil moisture changes in arid cereal land at Changwu arid-plateau. If reasonable crop database, soil database and meteorology database are built up into the EPIC model, the accuracy of simulated soil moisture will be increased.
\end{abstract}

Keywords: soil moisture, winter wheat, spring maize, EPIC model
Volume 6 Issue 3 - 2017

\author{
Wang Xue Chun, ${ }^{1,2}$ Muhammad Naveed \\ Tahir, ${ }^{1,3}$ Li Jun, ${ }^{1,2}$ Hao Ming De ${ }^{2}$ \\ 'College of Agronomy, Northwest A \& F University, Yangling, \\ China \\ 2Institute of Soil and Water Conservation, CAS \& MWR, \\ Yangling, China \\ ${ }^{3}$ Department of Agronomy, PMAS-Arid Agriculture University \\ Rawalpindi, Pakistan
}

\begin{abstract}
Correspondence: Muhammad Naveed Tahir, College of Agronomy, Northwest A \& F University, Yangling Shaanxi 712100,
\end{abstract} Email naveed@uaar.edu.pk, langzi0509@sina.com

Received: August 04, 2016 | Published: February 10, 2017

\section{Introduction}

The Environmental Policy Integrated Climate Model (EPIC, formerly known as the Erosion Productivity Impact Calculator) is one of the predominant crop models which can be used to simulate the process of long-term changing of soil water resource and crop productivity. ${ }^{1}$ However, there is a necessity to justify EPIC model when it is applied to a specific situation which is not same as its birthplace, Black Land Research Center of America. ${ }^{2-7}$

Few studies found to estimate its simulation accuracy of soil water, though great progress had been made on its ability to simulate soil water. Aiming to evaluate the effect of soil and water resources on crop production, the EPIC model built up at Black Land Research Center and named it Erosion Productivity Impact Calculator. ${ }^{1}$ After it was build up, many efforts had been made to improve its capacity to simulate soil water. Jones et al. ${ }^{8}$ improved the crop growth model, one sub-model of EPIC model, by modifying the growth and distribution of crop's roots, and made its simulation results of root distribution of crop more reasonable. Williams et al., ${ }^{9}$ brought three erosion equations (MUSS, MUST and MUSI) into EPIC model. Renard ${ }^{10}$ took RUSLE equation into EPIC model. These equations brought out a higher accuracy for EPIC model to simulate the runoff. Roloff et al., ${ }^{11}$ took an equation, which was called Baier-Robertson and was used to calculate the potential evaporation of plant, into the EPIC model. Williams et al., ${ }^{12}$ added an infiltration equation (Green and Ampt) into EPIC model. All these efforts made to EPIC model improved its capacity to simulate soil water; however, few research reports were founded to evaluate its simulation results of soil moisture. EPIC model has been modified and applied by lots of scientists, since it was introduced into China. Wang et al., ${ }^{13}$ researched potential productivity of spring maize and winter wheat on the Loess Plateau of China and their results showed that spring maize yield was precisely simulated by modified EPIC model. Li et al., ${ }^{14-17}$ presented the frame and theory of EPIC model from 2004 to 2005, and they built up the basis foundation for the application of this model on the Loess Plateau of China. Wang et al. ${ }^{18}$ while Chen et al., ${ }^{19}$ evaluated the simulation results of winter wheat and alfalfa respectively, their simulation results showed that the law of yield change of winter wheat and alfalfa were predicted well by EPIC model. Chun et al., ${ }^{20}$ studied alfalfa growth by EPIC model in Beijing city, and this study showed that biomass of alfalfa in different growth period was estimated well by EPIC model.

However, few researches were reported to evaluate the simulation results of soil water on the Loess Plateau of China. Li et al., ${ }^{14-17}$ evaluated the simulation results of total soil water year by year and their research indicted annually total soil water (in $0-6 \mathrm{~m}$ soil) were simulated well by EPIC model. However, model still showed lack in its accuracy to simulate monthly soil water and its distribution of soil water in different soil layers. So there are still some uncertainties for the simulation results of EPIC model for soil water on the Loess Plateau of China. For example, research about alfalfa in Beijing city of China by Chun et al. ${ }^{20}$ showed that simulated soil water did not agree well with the observed value because the parameters of EPIC model were not modified based on the local situation in his research. It showed the need of necessary amendment and evaluation based on local or regional situation by modification of EPIC parameters, before using it to research the soil water, which is a key factor of crop production for this region. 
The objective of this paper was to evaluate the simulation results of monthly soil water and its distribution in different soil layers, using measured data of fixed long-term experiments (1987 to 1996) at Changwu Agriculture Station on the Loess Plateau of China.

\section{Materials and methods}

\section{Site description and long-term experiment}

In China, the Loess Plateau located in the upper-middle reaches of the Yellow River, and bordered on Taihang Mountain in the east, Reyue-Helan Mountain in the west, Qinling Mountain in the south and Yinsan Mountain in the north $\left(100.90^{\circ}-114.51^{\circ} \mathrm{E}\right.$ and $33.70^{\circ}$ $41.26^{\circ} \mathrm{N}$ ), covers a total area of $62.85 \times 104 \mathrm{~km}^{2}$, with its elevation ranging within $1200-1600 \mathrm{~m}$ above sea level, and its loess cover mainly ranging from 30 to $80 \mathrm{~m}$ thick. This region is a transitional zone between the southeastern humid monsoon climate and the northwestern continental dry climate with its Annual precipitation ranging from 200 to $750 \mathrm{~mm}$, its annual mean temperature varying between 8.6 and $13.58 \mathrm{C}$, and its frost-free period ranging from 185 to 210 days.

Shilipu village $\left(36^{\circ} 02^{\prime} \mathrm{N}, 104^{\circ} 25^{\prime} \mathrm{E}\right)$, the middle region of the Loess Plateau, is located in Changwu county of Shaanxi province China. It is a semi-humid continental monsoon climate zone and is a representative rain-fed area of China. Its mean annual precipitation is $578.5 \mathrm{~mm}$, its mean temperature is $9.1^{\circ} \mathrm{C}$, and its mean frost-free period is $171 \mathrm{~d}$. Its predominant soil type is heilu soil (silt content is about $65-75 \%$, clay content is about $18-25 \%$ ). Field capacity of this soil (by weight) is $22 \%$, and its wilting point is $8 \%$. Its primary crops are winter wheat and spring maize. Field experiments with mono winter wheat and mono spring maize were carried out at Shilipu Village from 1987 to 1996 . Fertilizer for winter wheat and spring maize were as following. Pure N was $120 \mathrm{~kg} / \mathrm{hm}^{2}$; pure $\mathrm{P}_{2} \mathrm{O}_{5}$ was 60 $\mathrm{kg} / \mathrm{hm}^{2}$; stable manure (organic matter content was $44.29 \mathrm{~g} / \mathrm{kg}$ ) was $75000 \mathrm{~kg} / \mathrm{hm}^{2}$. Winter wheat was sown in late-September and its grain yield was measured in mid-June each year. Spring maize was sown in late-April and its grain yield was measured in late-September each year. Soil water in $0-2 \mathrm{~m}$ soil was measured by core break method ${ }^{21}$ on the $20^{\text {th }}$ day of each month from 1987 to 1996 . Soil water content was measured (gravimetrically) for each soil sample by the oven-drying method. ${ }^{22}$

Table I Different rainfall years of Changwu meteorological station from 1987 to 1996

\begin{tabular}{lll}
\hline $\begin{array}{l}\text { Type of rain fall } \\
\text { years }\end{array}$ & $\begin{array}{l}\text { Annual } \\
\text { precipitation }\end{array}$ & Year \\
\hline Extreme rainy years & $>700 \mathrm{~mm}$ & 1988 \\
Rainy years & $600-700 \mathrm{~mm}$ & 1990 and I996 \\
$\begin{array}{l}\text { Normal years } \\
\text { Drought years }\end{array}$ & $400-600 \mathrm{~mm}$ & $1987,1989,1992,1993$ \\
$\begin{array}{l}\text { Extreme drought } \\
\text { years }\end{array}$ & $<400 \mathrm{~mm}$ & 1991 and I994 \\
\hline
\end{tabular}

\section{Crop parameters}

Based on crop parameters and other related parameters, the EPIC model can be adopted to calculate the uptakes of soil water and nutrients by crop, estimate the impacts of temperature, water, nutrients (N, P and $\mathrm{k}$ ), air and salt stresses on crop biomass accumulation and crop yield, and examine the process of crop growth by daily step. In this study, relevant crop parameters (Table 2) were modified based on the measured and published data. ${ }^{22-26}$

Table 2 Important revised vegetal parameters of winter wheat and spring maize in the EPIC model

\begin{tabular}{lll}
\hline Parameters & Winter wheat & Spring maize \\
\hline WA & 30 & 40 \\
HI & 0.4 & 0.5 \\
TB & 15.5 & 25.5 \\
TG & 0 & 8 \\
DMLA & 6 & 6 \\
DLAI & 0.91 & 0.8 \\
RLAD & 1 & 1 \\
RBMD & 1 & 1 \\
GSI & 0.007 & 0.007 \\
HMX & 1.2 & 2 \\
RDMX & 4 & 4 \\
FRSTI & 15.2 & 5.01 \\
FRST2 & 25.5 & 15.95 \\
RWPC1 & 0.4 & 0.4 \\
RWPC2 & 0.2 & 0.2 \\
\hline
\end{tabular}

\section{Soil data}

In the EPIC model, soil data was stored in the file named SOIL DATA. In this study, $6 \mathrm{~m}$ soil was divided into 9 layers (Table 3 ) based on the measured data and soil survey books published in China. Its mean bulk density was $1.32 \mathrm{~g} / \mathrm{cm}^{3}$ with mean field capacity was $0.27 \mathrm{~m} / \mathrm{m}$ and mean wilting point was $0.13 \mathrm{~m} / \mathrm{m}$. Water and wind erosion were not taken into account in the EPIC model.

\section{Meteorological data}

The meteorological data (Table 4), including daily maximum temperature, daily minimum temperature, daily precipitation, daily wind speed, daily relative humidity and daily sunshine hours, were obtained from Changwu meteorological station. In this study, sunshine radiation, needed by EPIC model, was translated from sunshine hours, recorded at Changwu meteorological station, based on equations suggested by Li et al., ${ }^{14}$

\section{Management parameters}

All other management parameters and equipments were built up into the EPIC model based on location situations. Two crop systems (mono winter wheat and mono spring maize) were built up into the ROTATION file; parameters of equipment for planting, harvest and fertilizers, were modified based on local situations; three kinds of fertilizer (urea, pure $\mathrm{P}_{2} \mathrm{O}_{5}$ and stable manual) were added into the EPIC model by the filed named FERMAN. 
Table 3 Important physical and chemical parameters of heilu soil

\begin{tabular}{|c|c|c|c|c|c|c|c|c|c|}
\hline layer number & I & 2 & 3 & 4 & 5 & 6 & 7 & 8 & 9 \\
\hline Layer depth (m) & 0.1 & 0.5 & I & 1.5 & 2 & 3 & 4 & 5 & 6 \\
\hline Field capacity $(\mathrm{m} / \mathrm{m})$ & 0.28 & 0.28 & 0.28 & 0.28 & 0.28 & 0.27 & 0.27 & 0.27 & 0.26 \\
\hline Wilting point $(\mathrm{m} / \mathrm{m})$ & 0.1 & 0.1 & 0.11 & 0.11 & 0.12 & 0.13 & 0.13 & 0.13 & 0.14 \\
\hline Bulk density $(\mathrm{g} / \mathrm{cm} 3)$ & 1.3 & 1.3 & I.31 & 1.31 & 1.32 & 1.32 & 1.33 & 1.33 & 1.33 \\
\hline $\mathrm{PH}$ & 8.2 & 8.2 & 8.2 & 8.3 & 8.4 & 8.3 & 8.2 & 8.2 & 8.3 \\
\hline Action exchange capacity (cmol/kg) & 9.6 & 9.6 & 9.9 & 12.2 & 8.6 & 9.7 & 6.5 & 4.5 & 3.5 \\
\hline Calcium carbonate (\%) & 8 & 8 & 6.8 & 7 & 14.2 & 11.9 & 0 & 0 & 0 \\
\hline Phosphorus (ppm) & 4 & 4 & 3 & 3 & 2 & 2 & 0 & 0 & 0 \\
\hline Initial nitrate concentration (ppm) & 30 & 50 & 50 & 40 & 30 & 20 & 0 & 0 & 0 \\
\hline Organic nitrogen (ppm) & 613 & 613 & 452 & 553 & 400 & 480 & 0 & 0 & 0 \\
\hline Organic carbonate (\%) & 0.62 & 0.62 & 0.45 & 0.55 & 0.45 & 0.58 & 0 & 0 & 0 \\
\hline
\end{tabular}

Table 4 Monthly statistical meteorological parameters at Changwu station, Shaanxi province China

\begin{tabular}{|c|c|c|c|c|c|c|c|c|c|c|c|c|}
\hline Items & Jan. & Feb. & Mar. & Apr. & May. & Jun. & Jul. & Aug. & Sep. & Oct. & Nov. & Dec. \\
\hline WSPD & 2.02 & 2.23 & 2.56 & 2.77 & 2.54 & 2.39 & 2.49 & 2.32 & 2.01 & 1.93 & 2.05 & 1.9 \\
\hline TMX & 1.14 & 3.96 & 10.07 & 16.94 & 21.75 & 26.22 & 27.73 & 26.3 & 20.54 & 14.82 & 8.1 & 2.58 \\
\hline TMN & -9.87 & -6.45 & -0.69 & 4.81 & 9.16 & 13.32 & 17.03 & 16.08 & 10.96 & 4.97 & -1.88 & -7.88 \\
\hline SKWS & 1.26 & 0.85 & 0.72 & 1.01 & 0.8 & 0.72 & 0.5 & 0.72 & 0.84 & 0.9 & I.I & 1.03 \\
\hline SKRF & 1.67 & 1.35 & 1.25 & 2.3 & 2.78 & 2.54 & 1.73 & 2.45 & 1.78 & 2.05 & 2.48 & 2.36 \\
\hline SDWS & 1.21 & 1.17 & 1.23 & 1.3 & 1.17 & 1.01 & 1.03 & I.II & 1.05 & I.I & 1.26 & 1.16 \\
\hline SDRF & 1.53 & 1.92 & 4.03 & 7.54 & 8.36 & 8.72 & 12.43 & 14.8 & 10.19 & 6.6 & 4.68 & 2.2 \\
\hline SDMX & 4.17 & 5.17 & 5.39 & 5.3 & 4.69 & 3.96 & 3.6 & 3.78 & 4.31 & 4.41 & 4.7 & 4.35 \\
\hline SDMN & 3.53 & 3.92 & 3.39 & 3.65 & 3.41 & 2.87 & 2.33 & 2.67 & 3.29 & 3.88 & 3.9 & 3.8 \\
\hline RHUM & 0.59 & 0.61 & 0.63 & 0.63 & 0.65 & 0.64 & 0.73 & 0.77 & 0.8 & 0.78 & 0.72 & 0.64 \\
\hline RAD & 7 & 8.1 & 9.9 & 12.3 & 14.1 & 14.8 & 14.1 & 13 & 9.6 & 7.9 & 6.9 & 6.4 \\
\hline PW|W & 0.29 & 0.27 & 0.32 & 0.34 & 0.36 & 0.35 & 0.43 & 0.38 & 0.52 & 0.48 & 0.43 & 0.21 \\
\hline PW|D & 0.05 & 0.06 & 0.11 & 0.15 & 0.17 & 0.19 & 0.22 & 0.21 & 0.21 & 0.15 & 0.08 & 0.03 \\
\hline PRCP & 5.5 & 7.4 & 22.7 & 42 & 53.3 & 57.5 & 104 & 102 & 92.9 & 51.9 & 20.8 & 3.7 \\
\hline ETMX & 15.7 & 21.3 & 24.7 & 30.9 & 33.9 & 36.9 & 37.6 & 36 & 34.3 & 28.7 & 20.9 & I7.I \\
\hline ETMN & -22 & -20.3 & -12.5 & -8.8 & -1.7 & 4 & 9 & 7.3 & -0.5 & -8.5 & -16.7 & -25.2 \\
\hline DAYW & 0.42 & 0.27 & 0.38 & 0.78 & 0.4 & 0.11 & 0.11 & 0.11 & 0.13 & 0.16 & 0.36 & 0.2 \\
\hline DAYP & 2.18 & 2.4 & 4.47 & 5.71 & 6.56 & 6.89 & 8.71 & 7.98 & 9.16 & 7.04 & 4.11 & 1.27 \\
\hline AEMX & 8.47 & 12.9 & 19.6 & 25.9 & 29.2 & 32.22 & 33.04 & 31.67 & 27.41 & 21.69 & $|5.8|$ & 9.86 \\
\hline AEMN & -16 & -13.6 & -7.2 & -2.2 & 2.1 & 7.4 & 12.2 & 10.8 & 4.6 & -2.3 & -9.1 & -14.5 \\
\hline
\end{tabular}

\section{Results and analysis}

\section{Soil water in mono winter wheat field}

In 1987 to 1996, the mean simulated monthly soil moisture in $0-2 \mathrm{~m}$ soil depth was $0.207 \mathrm{~m} / \mathrm{m}$ and the mean measured monthly soil moisture in $0-2 \mathrm{~m}$ soil depth was $0.201 \mathrm{~m} / \mathrm{m}$ (Table 5). The correlation coefficient between simulated and measured soil moisture was 0.888 $(\mathrm{p}<0.01)$, with Root Mean Square Errors (RMSE) was $0.023 \mathrm{~m} / \mathrm{m}$ and Relative Root Mean Square Errors (RRMSE) was 11.4\%. Statistical values among different years were significantly different for simulated and observed soil moisture in $0-2 \mathrm{~m}$ soil depth. Between simulated and measured soil moisture, the values of correlation coefficients, relative errors, RMSE and RRMSE were $0.860(\mathrm{p}<0.05), 7.4 \%, 0.027 \mathrm{~m} / \mathrm{m}$ and $17 \%$, respectively in extreme drought years; $0.919(\mathrm{p}<0.01), 3.9 \%$, $0.022 \mathrm{~m} / \mathrm{m}$ and $12 \%$, respectively in drought years; $0.926(\mathrm{p}<0.01)$, $0.2 \%, 0.023 \mathrm{~m} / \mathrm{m}$ and $11 \%$ in normal years; $0.874(\mathrm{p}<0.01), 6.6 \%$, $0.028 \mathrm{~m} / \mathrm{m}$ and $14 \%$ in rainy years; $0.802(\mathrm{p}<0.05), 2.6 \%, 0.029 \mathrm{~m} / \mathrm{m}$ and $13 \%$ in extreme rainy years. 
Table 5 Comparison of simulated and measured soil moisture in different soil layers in winter wheat field on Changwu arid-plateau. $* *$ means $p<0.0$ I

\begin{tabular}{|c|c|c|c|c|c|}
\hline & $0-0.1 \mathrm{~m}$ & $0.1-0.5 \mathrm{~m}$ & $0.5-1.0 \mathrm{~m}$ & $1.0-1.5 \mathrm{~m}$ & I.5-2.0m \\
\hline Measured $(\mathrm{m} / \mathrm{m})$ & 0.234 & 0.192 & 0.204 & 0.189 & 0.187 \\
\hline Simulated $(\mathrm{m} / \mathrm{m})$ & 0.234 & 0.195 & 0.217 & 0.199 & 0.188 \\
\hline Relative error (\%) & 0 & 1.6 & 6.4 & 5.3 & 0.5 \\
\hline Correlation coefficient & $0.884 * *$ & $0.901 * *$ & $0.921 * *$ & $0.820 * *$ & $0.916 * *$ \\
\hline $\operatorname{RMSE}(\mathrm{m} / \mathrm{m})$ & 0.032 & 0.023 & 0.025 & 0.025 & 0.012 \\
\hline RRMSE (\%) & 14 & 12 & 12 & 13 & 6 \\
\hline Regression equation & $y=0.85 x+0.06$ & $y=0.81 x+0.04$ & $y=1.14 x-0.02$ & $y=1.13 x-0.02$ & $y=1.09 x-0.01$ \\
\hline
\end{tabular}

In mono winter wheat filed, soil moisture was predicted well generally by EPIC model comparing with measured data (Figure 1). The measured and simulated winter wheat yields uniformly distributed near the line of $\mathrm{y}=\mathrm{x}$, and the interceptions for their regression equations were near to 0 , the regression index was near to 1 . Most simulated values $(97 \%$ in average) were scattered between the line $\mathrm{y}=\mathrm{x}+$ ST $\mathrm{x}$ and the line $\mathrm{y}=\mathrm{x}-\mathrm{ST}$ (Figure 1). X was the measured soil moisture, STx was the standard deviation of measured soil moisture and $\mathrm{y}$ is the simulated soil moisture. The distribution of simulated and measured soil moisture was different in different soil layers (Figure 1). In $0-0.1 \mathrm{~m}, 0.1-0.5 \mathrm{~m}$ and $1.5-2.0 \mathrm{~m}$ soil layers, comparing with 0.5 $1.0 \mathrm{~m}$ and $1.0-1.5 \mathrm{~m}$ soil layers, there was a less distance between the value of regression index and 1 . There were more values departure from the line $y=x$ in $0.5-1.0 \mathrm{~m}$ and $1.0-1.5$ soil layers than in other three layers. Soil moisture was generally predicted well by EPIC model comparing with measured data. $a$ is the line $y=x+S T x ; b$ is the line $y=x ; c$ is the line $y=x-S T x ; y$ is the simulated soil moisture, $x$ is the observed soil moisture, STx is the standard deviation of observed soil moisture; 0-0.1m, 0.1-0.5m, 0.5-1.0m, 1.0-1.5m and $1.5-2.0 \mathrm{~m}$ are the different soil layers.

\section{Soil water in mono spring maize field}

In 1987 to 1996 , the mean simulated monthly soil moisture in $0-2 \mathrm{~m}$ soil was $0.215 \mathrm{~m} / \mathrm{m}$ and the mean measured monthly soil moisture in $0-2 \mathrm{~m}$ soil was $0.216 \mathrm{~m} / \mathrm{m}$ (Table 6). The Correlation coefficients between the simulated and the measured soil moisture was 0.943 $(\mathrm{p}<0.01)$ with RMSE was $0.015 \mathrm{~m} / \mathrm{m}$ and RRMSE was $7 \%$. Statistical values among different rainfall years were different for simulated and observed soil moisture in $0-2 \mathrm{~m}$ soil depth. Between simulated and measured soil moisture, the values of correlation coefficient, relative error, RMSE and RRMSE were $0.844(\mathrm{p}<0.05),-2.9 \%, 0.019 \mathrm{~m} / \mathrm{m}$ and $10 \%$, respectively in extreme drought years; $0.909(\mathrm{p}<0.01), 0.0 \%$, $0.012 \mathrm{~m} / \mathrm{m}$ and $6 \%$, respectively in drought years; $0.966(\mathrm{p}<0.01)$, $0.4 \%, 0.009 \mathrm{~m} / \mathrm{m}$ and $4 \%$ in normal years; $0.885(\mathrm{p}<0.01),-1.1 \%$, $0.015 \mathrm{~m} / \mathrm{m}$ and $7 \%$ in rainy years; $0.823(\mathrm{p}<0.05),-2.8 \%, 0.024 \mathrm{~m} / \mathrm{m}$ and $10 \%$ in extreme rainy years.

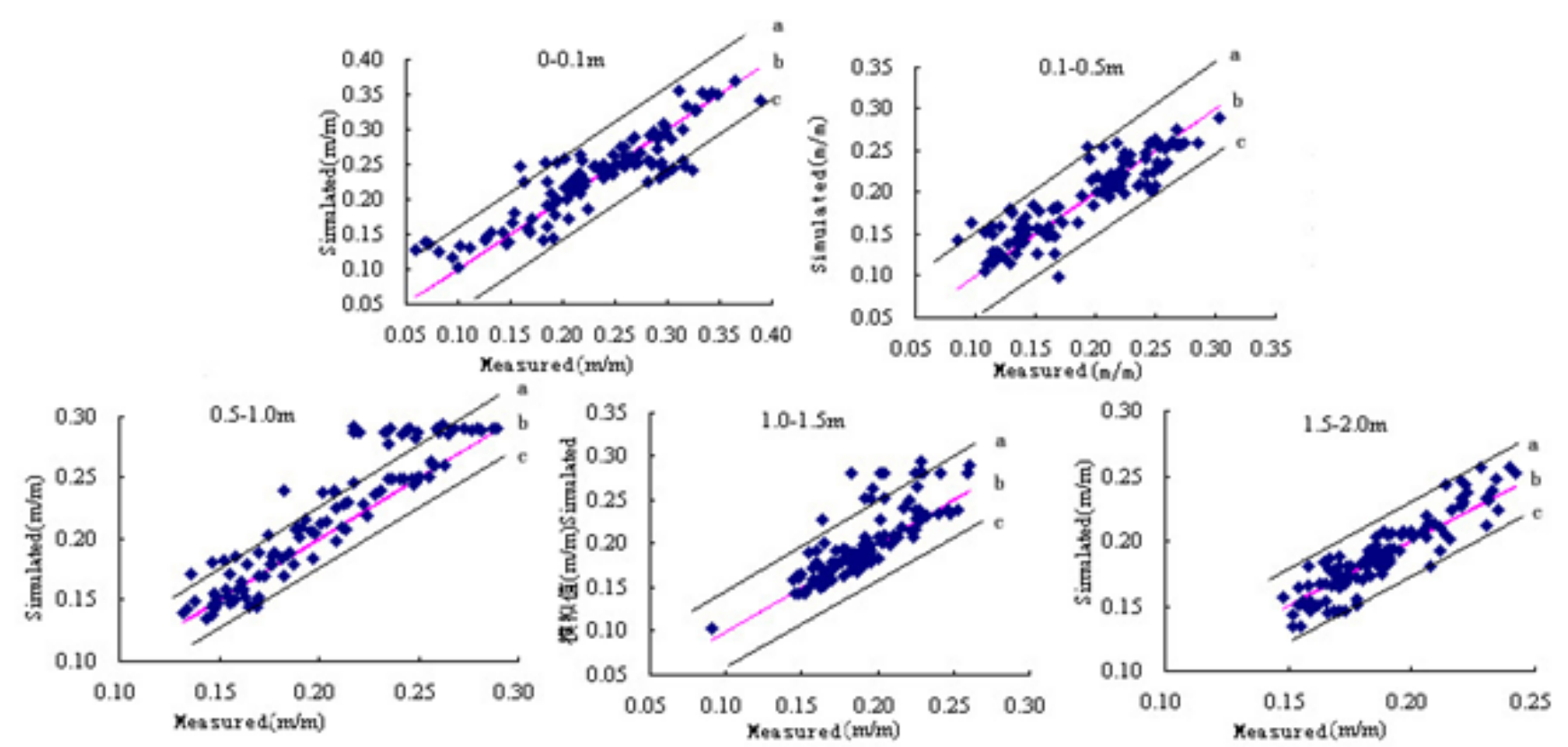

Figure I Comparison of simulated and measured soil moisture in different soil layers in winter wheat field on Changwu arid-plateau.Comparison of simulated and measured soil moisture in different soil layers in winter wheat field on Changwu arid-plateau. 
Soil moisture was estimated well generally, comparing with measured data, in mono spring maize field (Figure 2). The measured and simulated soil moisture uniformly distributed near the line of $y=x$, and the interceptions for their regression equations were near to 0 , their regression index were near to 1. Most simulated value (99\% in average) distributed among the line $y=x+S T x$ and the line $y=x-S T x$ (Figure 2). X was the measured soil moisture, STx was the standard deviation of measured soil moisture and $\mathrm{y}$ is the simulated soil moisture. The distribution of simulated and measured soil moisture in mono spring maize field was different in different soil layers (Figure
2). In $0.5-1.0 \mathrm{~m}, 1.0-1.5 \mathrm{~m}$ and $1.5-2.0 \mathrm{~m}$ soil layers, comparing with that in $0-0.1 \mathrm{~m}$ and $0.1-0.5 \mathrm{~m}$ soil layers, there was a less distance between the value of regression index and 1 . There were more values departure from the line of $\mathrm{y}=\mathrm{x}$ in $00.1 \mathrm{~m}$ and $0.1-0.5$ soil layers than in the other three layers. $a$ is the line $y=x+S T x ; b$ is the line $y=x ; c$ is the line $\mathrm{y}=\mathrm{x}-\mathrm{ST} \mathrm{x}$; $\mathrm{y}$ is simulated soil moisture, $\mathrm{x}$ is the observed soil moisture, STx is the standard deviation of observed soil moisture; $0-0.1 \mathrm{~m}, 0.1-0.5 \mathrm{~m}, 0.5-1.0 \mathrm{~m}, 1.0-1.5 \mathrm{~m}$ and $1.5-2.0 \mathrm{~m}$ are the different soil layers.

Table 6 Comparison of simulated and measured soil moisture in different soil layers in spring maize field on Changwu arid-plateau.* means $p<0.05 ; * * m e a n s$ $\mathrm{p}<0.01$.

\begin{tabular}{llllll}
\hline & $0-0.1 \mathrm{~m}$ & $0.1-0.5 \mathrm{~m}$ & $0.5-1.0 \mathrm{~m}$ & $1.0-1.5 \mathrm{~m}$ & $1.5-2.0 \mathrm{~m}$ \\
Measured $(\mathrm{m} / \mathrm{m})$ & 0.234 & 0.196 & 0.213 & 0.219 & 0.217 \\
Simulated $(\mathrm{m} / \mathrm{m})$ & 0.228 & 0.199 & 0.212 & 0.219 & 0.218 \\
Relative error $(\%)$ & -2.6 & 1.5 & -0.5 & 0 & 0.5 \\
Correlation coefficient & $0.940^{* *}$ & $0.928^{* *}$ & $0.920^{* *}$ & $0.966^{* *}$ & $0.963^{* *}$ \\
RMSE $(\mathrm{m} / \mathrm{m})$ & 0.023 & 0.017 & 0.017 & 0.009 & 0.008 \\
RRMSE $(\%)$ & 10 & 9 & 8 & 4 & 4 \\
Regression equation & $y=0.88 x+0.02$ & $y=0.87 x+0.03$ & $y=0.96 x+0.01$ & $y=0.97 x+0.01$ & $y=1.06 x-0.01$ \\
\hline
\end{tabular}
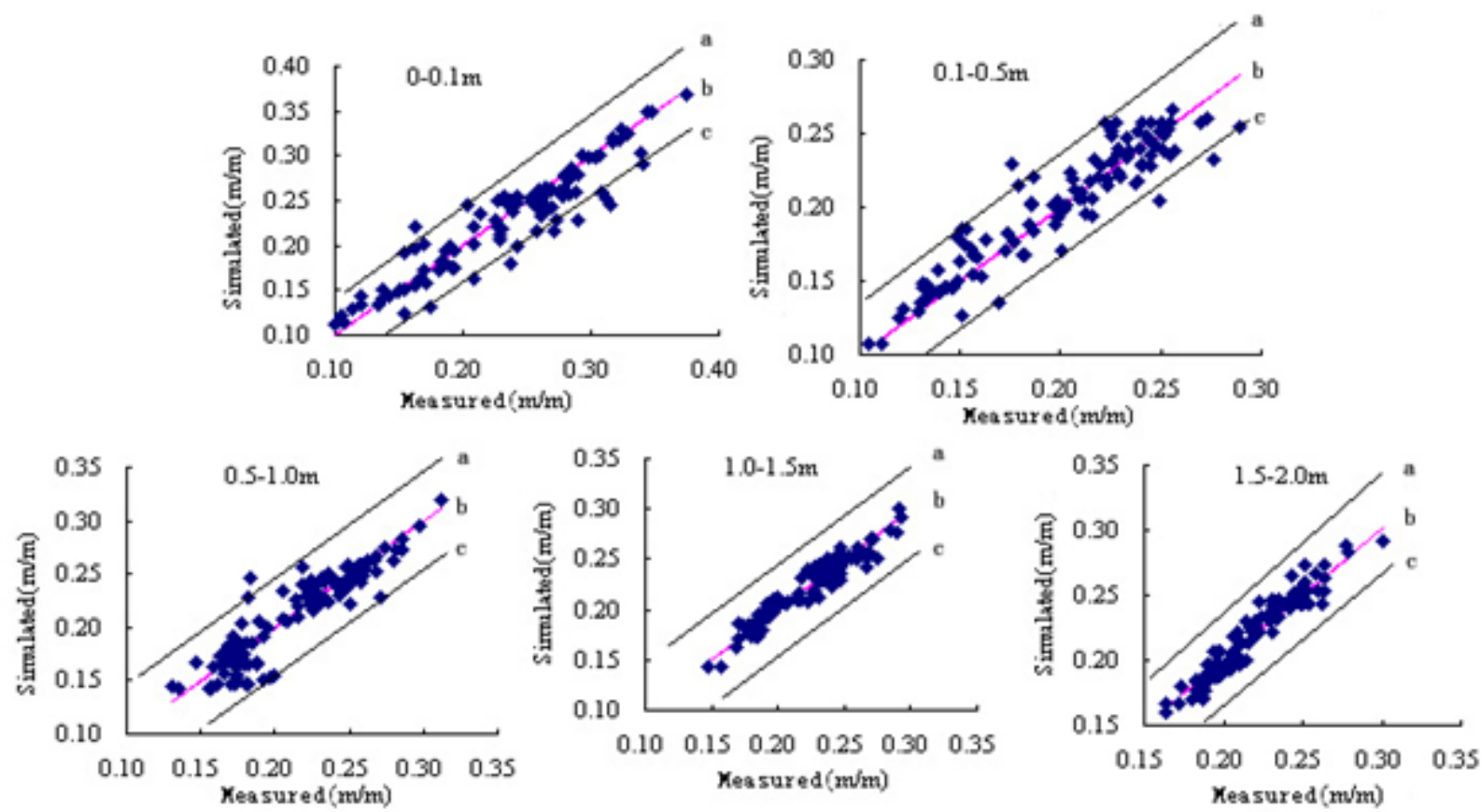

Figure 2 Comparison of simulated and observed soil moisture in different soil layers in spring maize land on Cahngwu arid-plateau.

\section{Discussion}

This study showed that soil moisture were predicted well comparing with measured value in different soil layers, either in mono winter wheat field or in mono spring maize field (Table $5 \& 6$ ), though the mean simulated moisture was higher than mean measured value in winter wheat field and was lower than mean measured value in mono spring maize field. Mean monthly soil moistures in $0-2 \mathrm{~m}$ depth soil were $0.207 \mathrm{~m} / \mathrm{m}$ and $0.201 \mathrm{~m} / \mathrm{m}$ for simulated and measured in mono winter wheat field, respectively. Mean monthly soil moistures in $0-2 \mathrm{~m}$ depth soil were $0.215 \mathrm{~m} / \mathrm{m}$ and $0.216 \mathrm{~m} / \mathrm{m}$ for simulated and measured in mono spring maize field, respectively. The relation between simulated and observed soil moisture was significant; the significant level was lower than 0.01; and the RRMSE was lower than 0.03 , both in mono winter wheat field and in mono spring maize field.

The accuracy of simulated soil moisture was higher in mono spring maize field than in mono winter wheat field. Correlation coefficient between simulated and measured soil moisture in $0-2 \mathrm{~m}$ depth soil was higher and the value of RRMSE was lower in mono spring maize field compared with mono winter wheat field. In EPIC model, meteorological data, soil data and other data of control table for mono winter wheat were the same as them for mono spring maize, so the difference of estimated accuracy of soil moisture between mono 
winter wheat field and mono spring maize field was produced by the difference of crop data of winter wheat and spring maize. Therefore, the estimated accuracy of soil moisture was relative to the crop data in EPIC model.

EPIC model satisfactorily simulated and measured soil moisture in different rain fall years, though it was influenced by the amount of annual rainfall and its accuracy were some lower in extreme rainfall years. The mean correlation coefficients between simulated and measured soil moisture in $0-2 \mathrm{~m}$ soil depth, (Table 1) of the classified years (drought years, normal years and rainy years) were $0.880(\mathrm{p}<0.01)$ and $0.938(\mathrm{P}<0.01)$ in mono winter wheat filed and mono spring maize field respectively. Its value of two extreme rainfall years (extreme rainy years and extreme drought years) were $0.831(\mathrm{P}<0.05)$ and $0.833(\mathrm{P}<0.05)$ in mono winter wheat field and mono spring maize field, respectively. The value of RMSE were generally lower in drought years, normal years and rainy years, compared with in extreme drought years and extreme rainy years. From 1987 to 1996 , there were only one year (1988) was extreme rainy year and one year (1995) was extreme drought year, i.e. their appearance probability was $20 \%$. Considering from a longer period (1957-2008), the appearance probability of extreme years, extreme rainy years or extreme drought years was lower $(<10 \%)$. Though the accuracy of simulated soil moisture in extreme rainfall years was lower than other rainfall years, the significant level of correlation coefficient was lower than 0.05 . Therefore the simulation results about soil moisture in arid land at Changwu arid plateau were generally reasonable.

The accuracy of estimated soil moisture will be higher, if reasonable soil database, crop database and meteorological database, based on the local or regional situation, are built up into the EPIC model. The distributions of simulated and measured soil moisture were more concentrated in mono spring maize field than it in mono winter wheat field (Figure 1) (Figure 2). These distributions in 1.0$1.5 \mathrm{~m}$ and $1.5-2.0 \mathrm{~m}$ soil layers were more concentrated than it in $0-0.1 \mathrm{~m}$ and $0.1-0.5 \mathrm{~m}$ soil layers, either in mono winter wheat filed or in mono spring maize field. The depletion of soil water by crop root was the key factor to influence the soil moisture in 1.0-2.0 soil layers, i.e. $1.0-1.5 \mathrm{~m}$ and $1.5-2.0 \mathrm{~m}$ soil layers, and it was influenced by potential Evapo-transpiration, one crop parameters of the EPIC model. Evaporation was the key factor to influence the soil moisture in $0-0.5 \mathrm{~m}$ soil layer, i.e. $0-0.1 \mathrm{~m}$ and $0.1-0.5 \mathrm{~m}$ soil layers, and it was influenced by the amount of sunshine radiation in meteorological database, the leaf area index in crop database and the equation to calculate soil moisture in the EPIC model. Benson et al. ${ }^{27}$ pointed out that the accuracy of simulation results of EPIC model were relative to the calculating equations chosen by the user of EPIC model, potential evapo-transpiration equation and soil moisture calculating equation. Roloff et al., ${ }^{11}$ believed that the accuracy of simulated soil water was relative to the amount of precipitation, the amount of sunshine radiation and the thickness of soil layers. When we amended the EPIC model, we found that the other soil parameters, such as the sand content, the silt content, the loam content and the buck density, could influence the accuracy of simulated soil water. Therefore, the reasonability of database for EPIC model was the key factor to influence the accuracy of simulation results.

\section{Conclusion}

i. The modified EPIC model can be used to estimate the soil moisture and then to research the law of soil water change of arid land in the Loess Plateau of China. Relative errors between simulated and observed soil moisture in $0-2 \mathrm{~m}$ depth soil were $2.8 \%$ and $-0.2 \%$ in mono winter wheat field and mono spring maize field respectively. Correlation coefficients were 0.888 and 0.943 respectively, RMSE were $0.023 \mathrm{~m} / \mathrm{m}$ and $0.015 \mathrm{~m} / \mathrm{m}$ respectively.

ii. There was a different accuracy of simulated soil moisture in different rainfall years. Comparing with the soil moisture in drought years, rainy years and normal years, there was a lower accuracy in extreme rainy years and extreme drought years. The highest accuracy appeared in normal years among all different rainfall years. Correlation coefficients between simulated and measured soil moisture in normal years were respectively 0.926 and 0.966 in mono winter wheat field and mono spring maize field; RMSE was $0.023 \mathrm{~m} / \mathrm{m}$ and $0.009 \mathrm{~m} / \mathrm{m}$ respectively.

iii. Crop parameters, amount of potential evaporation transpiration, soil parameters, equation to calculate soil moisture, and amount of rainfall can influence the accuracy of estimated soil moisture. Therefore its accuracy of estimated soil moisture will be increased, provided reasonable soil database, crop database and meteorological database, based on the local or regional situation, built up into the EPIC model.

\section{Acknowledgements}

This study was sponsored by the Chinese National Science Foundation (Project Nos $40371077 \& 30771280$ ). We are grateful to Williams J.R. with whom we had many discussions about the EPIC model. We also want to give our thanks to Fang X.Y. and Li X.F. with whom we had many discussions throughout preparing and writing this paper. Last but not least, we thank two anonymous reviewers for their constructive comments on the earlier version of this paper.

\section{Conflict of interest}

The author declares no conflict of interest.

\section{References}

1. Williams JR, Jones CA, Kiniry JR. The EPIC crop growth model. Trans. ASAE. 1989;32(2):475-511.

2. Rosenberg NJ, McKenney MS, Easterlin EW. Validation of EPIC model simulations of crop responses to current climate and $\mathrm{CO} 2$ conditions:comparisons with census, expert judgment and experimental plot data. Agric For Meteorol. 1992;59(1-2):35-51.

3. Mearns LO, Mavromatis T, Tsvetsinskaya E. Comparative response of EPIC and CERES crop models to high and low resolution climate change scenarios. J Geophys Res. 1999;104(D6):6623-6646.

4. Carbone GJ, Mearns LO, Mavromatis T. Evaluating CROPGROsoybean performance for use in climate impact studies. Agron J. 2003;95(3):537-544

5. Easterling EW, Chhetri N, Niu X. Improving the realism of modeling agronomic adaptation to climate change:simulating technological substitution. Clim Change. 2003;60(1):149-173.

6. Liu JG, Williams JR, Zehnder AJB. a GEPIC-modeling wheat yield and crop water productivity with high resolution on a global scale. Agric Sys. 2007;94(2):478-493.

7. Liu JG, Wiberg D, Zehnder AJB. Modeling the role of irrigation in winter wheat yield, crop water productivity and production in China. Irrig Sci. 2007;26(1):21-33.

8. Jones CA, Dyke PT, Williams JR. EPIC: an operational model for evaluation of agricultural sustainability. Agric Syst. 1991;37(4):341-50. 
9. Williams JR. The EPIC Model. In: Singh V.P. editor. Computer Models of Watershed Hydrology. Highlands Ranch CO. Colorado, USA: Water Resources Publications; 1995. p. 909-1000.

10. Renard KG. Predicting Soil Erosion by Water: A Guide to Conservation Planning with the Revised Universal Loss Soil Equation (RUSLE). Washington, DC:US Department of Agriculture, Agricultural Research Service; 1997

11. Roloff G, Jong RD, Zentner RP. Estimating Spring Wheat Yield Variability with EPIC. Can J Soil Sci. 1998;78(3):541-549.

12. Williams JR, Arnold JG, Srinivasan R. The APEX Model. BRC Report No. 00-06. Texas Agric Expt Station, Texas Agric Exten. Service Texas A\&M University; 2000.

13. Wang ZM, Liang YL. The application of EPIC model to calculate crop productive potentialities in losses yuan region. $J$ Natural Res. 2002;17(4):481-487.

14. Li J, Shao MA, Zhang XC. Simulation equations for crop growth and yield formation in the EPIC model. $J$ Northwest Sci-Tech Univ A\&F. 2004;32(s):25-31

15. Li J, Shao MA, Zhang XC. Database construction for the EPIC model on the Loess Plateau region. $J$ Northwest Sci-Tech Univ A\&F. 2004;32(8):21-26.

16. Li J, Shao MA, Zhang XC. Simulation of water potential productivity of winter wheat and soil water dynamics on rainfed highland of the Loess Plateau. J Natural Res. 2004;19(6):738-746.

17. Li J, Shao MA, Zhang XC. Simulation equations for soil nitrogen and phosphorus transfer and crop nutrition in the EPIC model. Plant Nutri Ferti Sci. 2005;11(2):166-173.
18. Wang XC, Li J, Hao M. Simulation of fertilization effect on winter wheat yield in Changwu dry highland. Trans. Chinese Soc Agri Eng. 2008;24(8):45-50

19. Chen B, Li J, Li XF. Long term simulation of water potential productivity of alfalfa on rain-fed highland in south of Loess Plateau. Agri Res Arid Areas. 2006;24(3):31-35.

20. Chun L, Yang DX, Xin XP. Simulation of Alfalfa first year growth using EPIC model in Beijing. Acta Agri Boreali-Sinica. 2007;22:163-166.

21. Bennie ATP, Taylor HM, Georgen PG. An assessment of the core-break method for estimating root density of different crops in the field. Soil Till Res. 1987;9(4):343-347.

22. Blake GR, Hartge KH. Bulk density. In: Klute A editor. Methods of soil analysis. Part I. Physical and Mineralogical Methods. 2nd ed. Agronomy 9, American Society of Agronomy, Madison WI; 1986. p. 363-382.

23. Wu TY, Yang XJ, Liu H. Correlation analysis on leaf characters and some main agronomic traits of wheat. J Anhui Agri Sci. 2009;37(1):94-96.

24. Wang XL, Yu HQ, Xia L. The difference in root morphological characteristics of different tolerance maize inbred line under drought stress. Modern Agri Sci. 2008;15(2):17-19.

25. Ma SC, Xu BC, Feng M. Effect root pruning on root distribution, root efficiency and yield formation of winter wheat in Loess Plateau. Acto Ecol Sinica. 2008;28(12):6172-6179.

26. Jiang SC. Researches on the growth curve of leaf area of corn. Modern Agri. 2009;2:12-15.

27. Benson VW, Potter KN, Bogusch HC. Nitrogen Leaching Sensitivity to evapotranspiration and Soil Water Storage Estimates in EPIC. Soil Water Cons. 1992;47(4):334-337 